\title{
Angels in Near-Death Experiences
}

\author{
Craig R. Lundahl, Ph.D. \\ Western New Mexico University
}

ABSTRACT: The literature on near-death experiences (NDEs) contains no substantive discussion of angels in NDEs, even though there are references to angels in several studies of these experiences. In this article I identify angels in NDEs and describe their functions in the NDE based on published NDE accounts. I conclude that angels are personages with whom the NDEr does not usually recall having previous acquaintance. Angels serve as guides, messengers, or escorts in the NDE.

References to angels in near-death experiences (NDEs) are found in several studies of the subject. Angels were referred to as "beings of light" by some near-death experiencers in Raymond Moody's book Life After Life (1975); in fact, Moody described the being of light as one of 15 elements in the NDE. In Moody's first case of a childhood NDE, a 9 year old boy was met on the other side by a group of angels whom he described as having no wings, glowing, and seeming to love him very much (Moody and Perry, 1988). Kenneth Ring (1982) cited the NDE of a man who came close to dying as a result of being ill during a tooth extraction, and took a trip to heaven where he saw angels.

In one of the most extensive narratives they received in their national survey of NDEs in the United States, George Gallup, Jr., and William Proctor (1982) related the account of a nurse who described angels holding hands to form a stairway to heaven. Once she reached

Craig R. Lundahl, Ph.D., is Professor of Sociology and Business Administration and Chair of the Department of Social Sciences at Western New Mexico University. This research was supported by a sabbatical leave granted by the Sabbatical Leave Committee of Western New Mexico University. Reprint requests should be addressed to Dr. Lundahl at the Department of Social Sciences, Western New Mexico University, Silver City, NM 88062. 
the top of this stairway she met another angel who suggested to her that she ask the Lord to let her go back to raise her child. In their comments on the extradimensional beings in this NDE, Gallup and Proctor differentiated between the hosts of anthropomorphic angels who held hands to form a stairway for her up to heaven, and the head angel of sorts who acted as spokesperson for the others and who explained to her some of the things that were going on and gave her some advice.

Craig Lundahl documented an account in which the NDEr recognized his guardian angel. The NDEr wrote: "My spirit left the body, and I could see it lying under the derrick, and at that moment my guardian angel, my mother, and my sister Ann were beside me. My mother died January 31, 1918, and my sister at the age of four years" (Lundahl, 1982, p. 172).

References to angels were mentioned in Closer to the Light, a book reporting the findings on childhood NDEs by Melvin Morse and Paul Perry (1990). In this book, Morse and Perry pointed out that many children describe guardian angels who are blond or "all white" who escort them to heaven. It was the NDE account of Katie that began Morse's fascination with these experiences, and led him to examine the testimony of young patients about their NDEs. In her NDE, Katie, a 9 year old girl, met Elizabeth, who seemed to Katie to be a guardian angel. Katie entered a tunnel that opened, and through the tunnel came Elizabeth, described by Katie as tall and nice with bright, golden hair. Elizabeth accompanied Katie up the tunnel, where she saw her late grandfather and met several other people, including two new friends. Later in this NDE, Elizabeth took Katie to meet Heavenly Father and Jesus.

Morse and Perry also described other children who encountered angels in their NDEs, including Dean, who was transported to heaven by an angel or someone whom he described as about seven feet tall with golden hair and wearing a long white gown with a simple belt tied at the waist; and Kurt, a 7 year old who saw angels in his NDE.

Through the centuries, in the Old Testament and the New Testament as well as in much of the religious literature outside the JudeoChristian tradition, angels played important roles and ministered to many people. In Islam, the angel Gabriel revealed great truths to the prophet Muhammad. In the Bible, the same angel appeared to Mary, announcing that she was pregnant with the Son of God. Among the many angels in Judaism, one is believed to have brought the traditional mourning prayer, the Kaddish, to earth from heaven.

Buddhism, Hinduism, and Native American religions also teach of beings similar to angels, and they are found in such great Judeo- 
Christian poetry as Dante Alighieri's Divine Comedy (c. 1300), Geoffrey Chaucer's Canterbury Tales (c. 1387), John Milton's Paradise Lost (1667), and Johann Wolfgang von Goethe's Faust (1808-1832). The 18th century Swedish scientist, philosopher, and religious writer Emanuel Swedenborg, who went through the early events of death, also encountered beings whom he identified as angels (Moody, 1975).

The skepticism of our age has discouraged any belief in angels. However, recently angels have become a subject of growing fascination in America. Books on the subject have become bestsellers, including Sophy Burnham's A Book of Angels (1990), which was number one for 15 weeks in 1991 on the Washington Post bestseller list. Burnham's newly released book Angel Letters (1991) contains accounts from people of different faiths and cultures who say they have met angels. Burnham claims she has interviewed nearly 400 people in the last few years with similar claims of having met angels.

Angels in NDEs seem to have been taken for granted or even ignored by near-death researchers. In fact, they have received little more attention than mention by NDErs themselves. But there are so many accounts of angels in NDEs that it is impossible to dismiss them without consideration. Furthermore, there is no question that they do play an important role in many NDEs. The fact remains, however, that substantive discussion of angels is absent from the literature on the NDE. The purpose of this article is to identify who angels are and to describe their functions in the NDE based on published NDE accounts.

\section{Who Are the Angels in Near-Death Experiences?}

Angels have been referred to as beings of light (Moody, 1975). In that book, Moody wrote that the being of light was the most incredible common element in the NDErs he studied. However, he stated that the identification of these beings seemed to vary with the NDEr's religious background. For example, Moody stated, a Jewish person might identify the being of light as an angel, whereas a Christian person might identify the being as Christ.

Gallup and Proctor (1982) found a relatively small 5 percent of those who had an NDE say they saw any lights at all. Although they felt that this light should not be regarded as typical or normative of NDEs, Gallup and Proctor nevertheless noted that 5 percent represented about a million adult Americans, and that is a substantial number of people to have had this type of experience. They pointed out that in almost every case where it was mentioned, the light became a very important part of the scene that the individual encountered. Gallup 
and Proctor reported that sometimes the light reported was soft and comforting, and at other times it was brilliant and blinding; on occasion, the light was connected with some sort of being or a group of beings in the extradimensional sphere.

Michele Sorensen and David Willmore have interviewed many Latter-Day Saints, and found that that group generally describe "the being of light as a deceased family member" $(1988, p .48)$. Sorensen and Willmore went on to say that in nearly every case the being was a guide.

So it appears that a being of light in the NDE may be identified as an angel or as a deceased family member, but there does not appear to be a published NDE account where the NDEr identified a being of light as both a family member and an angel. In other words, a deceased family member and an angel are not one and the same person, even though both may appear in a bright light. The following NDE account illustrates this point:

I had been gasping because of the pain, but somehow I just gave up and felt my last breath leave my mouth. At that instant, all the pain was gone, and I was flying at an enormous speed through darkness into a light. My flight stopped just with the darkness, and I gazed into the light, sensing the power that emanated from it.

My Grandmother appeared within this wonderful, pure light. She was smiling, totally at peace and harmony with herself and her surroundings; an indescribable purity and unconditional love emanated from her and the light toward me. Grandma spoke no words. The love said everything. Her eyes were filled with deepest compassion, and I was swept with overwhelming longing to enter into the light with her. (Sorensen and Willmore, 1988, p. 37)

It is also entirely possible that an angel need not necessarily appear as a being of light, and apparently that has been reported also in NDE accounts. Of course, whether an angel appears as a being of light or not may depend on the circumstances of the occasion. Gallup and Proctor (1982) reported that 8 percent of their national sample, or nearly two million of the eight million adult Americans reporting an NDE, described another being or beings present during the NDE. Gallup and Proctor's NDErs sometimes referred to these beings as dead relatives and at other times as angels or Jesus Christ, and some described angels as personages who have a human appearance.

Who then are angels? They are identified by NDErs as personages with whom they were usually not previously acquainted, who may or may not appear as a being of light. 


\section{Angelic Functions in Near-Death Experiences}

A study of NDE accounts suggests three major functions of angels in NDEs: they perform in the capacities of guide, messenger, or escort. In every case the Gallup Poll research team encountered in their national study in which the NDEr encountered angels, the NDEr reported that those beings acted as guides, messengers, or protectors (Gallup and Proctor, 1982). I will describe each of these roles and illustrate them with NDE accounts.

\section{Guide}

A guide may be described as one who leads or directs others and in the process may explain points of interest. One NDEr described the angel who guided him through a death experience in these words:

It was between 10 and 11 o'clock that a visitor suddenly made his appearance in the room, and standing by the couch on which I lay, placed his hand on my head and asked if I was ready to go. I answered, "Yes"; and just at that instant I seemed to stand upon the floor, my body lying on the bed. I looked around to see if my father could see us, but he seemed to have been too interested in reading to have noticed us. We started off on our journey through space, seemingly with the rapidity of lightning. I asked my guide who he was. He answered he was one of the guardian angels sent to bring the dead. We soon reached a place where was congregated a great number of peoplesomething similar to a market day in the old country. They seemed to have gathered for some purpose. I asked my guide what place this was, and he answered, "That is the place where all your forefathers have gathered together, and are waiting for two missionaries." There seemed to be a stand erected close by for the missionaries to preach in. They came as it were directly; part of the congregation were noisy and inclined to be troublesome. I asked my guide who these missionaries were, and he merely answered, "The old man is the Apostle Matthias." I understood by this it was the Apostle Matthias who had filled the place of Judas Iscariot who betrayed the Savior, and the young man, he further said, "was an apostle from America who had lately been killed there...."

My guide then introduced me to the apostles by bowing his head, which was returned by them. No hand shaking took place; the elder apostle said to me, "Would you as soon go back, for it seems to fall to redeem your forefathers?" I answered, "Yes, but my lungs are gone." He replied, "It is easy to grow new lungs in a man; if you will go your guide will attend to this." I answered, "I will go." 
With a bow we started to return and, seemingly, but a short space of time elapsed ere we reached my home, and standing by the bed, where my body lay, my guide touched my hands, the spirit entered my body at that instant, the blood commenced to circulate warmly through my veins, and in a few minutes I felt my lungs expanding. (Heinerman, 1978, pp. 108-111)

In this NDE account, the angel as guide came for the NDEr and took him through space. When the angel was asked who he was, he answered that he was one of many guardian angels with the responsibility to bring the dead, presumably to the other world. Even though the angel identified himself as a guardian angel, which may be his appropriate title in the other world, he seemed to act primarily as guide, as evidenced by his taking the NDEr to a place and explaining what place it was, and naming or describing the missionaries. Later, he introduced the NDEr to the missionaries, one of whom called the angel a "guide." Finally the angel returned the NDEr to his earthly home and used his power to return the NDEr's spirit to his body. In this NDE account, the NDEr's lungs were eventually healed, suggesting that the angel had it within his power to heal the NDErs' lungs as he was told to do.

\section{Messenger}

Some angels may serve to carry a message to the NDEr. In one account, a woman became seriously ill during her pregnancy and began to miscarry:

My body stayed right there, but my spirit started leaving. My husband began slapping my face, yet I couldn't respond. I knew that I was passing on, and I watched myself leaving.

Suddenly I started going through dimensions. There is no way to describe what happened. I was moving through our physical dimension into another one. The dimension did not stay in one shape or size, and I was aware that I was moving through circles and triangles and squares toward a bright light. I was so taken in by the sizes of things that I don't remember any colors.

Before I reached the light, I recalled my life in a sudden flash. It was the most totally exciting, fantastic thing I have ever seen. I saw the time I was brought from heaven to the earth by angels to a body, how I was received at the hospital, and how my parents loved me. From that day until the present, I saw everything that ever happened to me in my life. It was all in an instant.... 
I experienced this judgment as I was nearing the bright light. Then I saw someone coming toward me, with many other people behind him. He was an angel who had come to get me. I don't know who he was, but he was someone who had always helped me. We had been familiar with one another for a very long time, and it would have been ridiculous to make an introduction at this point. I was excited and wanted to express my happiness at the relief I felt from the cares of the world, but I was told that I had made some promises and commitments and had been set apart to do some work before this world was. I had accepted a responsibility that would have a great missionary effect. (Sorensen and Willmore, 1988, pp. 89-95)

In this NDE account, the personage in front of many other people was identified by the NDEr as an angel who came to get her. The commentary suggests that the major task of this angel was to give the NDEr a message about her promises and commitments to do some work. The angel did not take her on a tour in the other world explaining different points of interest or introducing her to other personages, as was the case in the first NDE account.

\section{Escort}

Finally, some angels have as their function to guard or protect the NDEr. This function is portrayed in the following account of an NDEr who contracted yellow fever:

Soon after that, my spirit left the body; just how I cannot tell. But I perceived myself standing some four or five feet in the air, and saw my body lying on the bed. I felt perfectly natural, but as this was a new condition I began to make observations. I turned my head, shrugged my shoulders, felt with my hands, and realized that it was I myself. I also knew that my body was lying, lifeless, on the bed. While I was in a new environment, it did not seem strange, for I realized everything that was going on, and perceived that I was the same in the spirit as I had been in the body. While contemplating this new condition, something attracted my attention, and on turning around I beheld a personage, who said: "You did not know that I was here."

I replied: "No, but I see you are. Who are you?"

"I am your guardian angel; I have been following you constantly while on earth."

I asked: "What will you do now?"

He replied: "I am to report your presence, and you will remain here until I return." 
He informed me, on returning, that we should wait there, as my sister desired to see me, but was busy just at that time. Presently she came. (Johnson, 1920, p. 451)

In this NDE account, the angel said, "I am your guardian angel; I have been following you constantly while on earth." This statement suggests that people may be watched over and even shielded from danger by what may be called guardian angels; however, it also suggests that the responsibility of a guardian angel is performed primarily outside the NDE. It appears in this case that the function of the guardian angel changed to that of an escort during the NDE, in which the guardian angel met the NDEr as he died, escorted him as he entered the afterlife, and reported his presence to the appropriate authority.

\section{Conclusion}

In many NDEs, angels play a significant role in fulfilling the purposes of the NDE, especially in those instances where the NDEr encounters the other world. Although many people today no longer believe in the ministry of angels, there is evidence that they appear in NDEs and fulfill needed functions of guide, messenger, and escort.

\section{References}

Burnham, S. (1990). A book of angels: Reflection on angels past and present and true stories of how they touch our lives. New York, NY: Ballantine.

Burnham, S. (1991). Angel letters: What you wrote to me. New York, NY: Ballantine.

Gallup, G., Jr., and Proctor, W. (1982). Adventures in immortality: A look beyond the threshold of death. New York, NY: McGraw-Hill.

Heinerman, J. (1978). Spirit world manifestations. Salt Lake City, UT: Magazine Printing and Publishing.

Johnson, P. E. (1920, August). A testimony. Relief Society Magazine, 3(8).

Lundahl, C. R. (1982). Near-death experiences of Mormons. In Lundahl, C. R. (Ed.), A collection of near-death research readings (pp. 165-179). Chicago, IL: Nelson-Hall.

Moody, R. A., Jr. (1975). Life after life. Covington, GA: Mockingbird.

Moody, R. A., Jr., and Kerry, P. (1988). The light beyond. New York, NY: Bantam.

Morse, M. L., and Perry, P. (1990). Closer to the light: Learning from the near-death experiences of children. New York, NY: Villard.

Ring, K. (1982). Frequency and stages of the prototypic near-death experience. In Lundahl, C. R. (Ed.), A collection of near-death research readings (pp. 110-147). Chicago, IL: Nelson-Hall.

Sorensen, M. R., and Willmore, D. R. (1988). The journey beyond life. Orem, UT: Family Affair. 